\title{
Nitrogen-rich groundwater intrusion affects productivity, but not herbivory, of the tropical seagrass Thalassia testudinum
}

\author{
Bradley J. Peterson*, Amber D. Stubler, Charles C. Wall, Christopher J. Gobler
}

School of Marine and Atmospheric Sciences, Stony Brook University, 239 Montauk Hwy, Southampton, New York 11968, USA

\begin{abstract}
Discovery Bay, Jamaica, is a coastal lagoon with areas of substantial submarine groundwater discharge that supply terrestrially derived nutrients to the marine ecosystem. The present study demonstrates that groundwater nitrogen delivery through the sediments allows benthic primary producers to utilize this resource. Meadows of Thalassia testudinum located within the discharge zone of the groundwater seepage had significantly more aboveground biomass, higher rates of productivity and leaves enriched in nitrogen. However, there were no observable positive impacts of nitrogen enrichment on epiphytic algal biomass within these areas. While recent studies have shown that herbivores preferentially graze seagrass blades with elevated tissue nitrogen levels, reciprocal transplant experiments revealed that herbivores avoided the nitrogenenriched leaves and preferentially consumed leaves that were stoichiometrically enriched in phosphorus when transplanted within groundwater areas. This finding suggests that herbivore grazing was influenced more by the ecological stoichiometry of these plants than by the absolute nitrogen content in this phosphorus-limited tropical marine system.
\end{abstract}

KEY WORDS: Submarine groundwater - Thalassia testudinum · Seagrass · Herbivory · Nitrogen tissue content

Resale or republication not permitted without written consent of the publisher

\section{INTRODUCTION}

Submarine groundwater discharge (SGD) is a phenomenon that occurs in coastal areas worldwide (Greenaway \& Gordon-Smith 2006). While SGD can occur at various depths and distances from the shore,

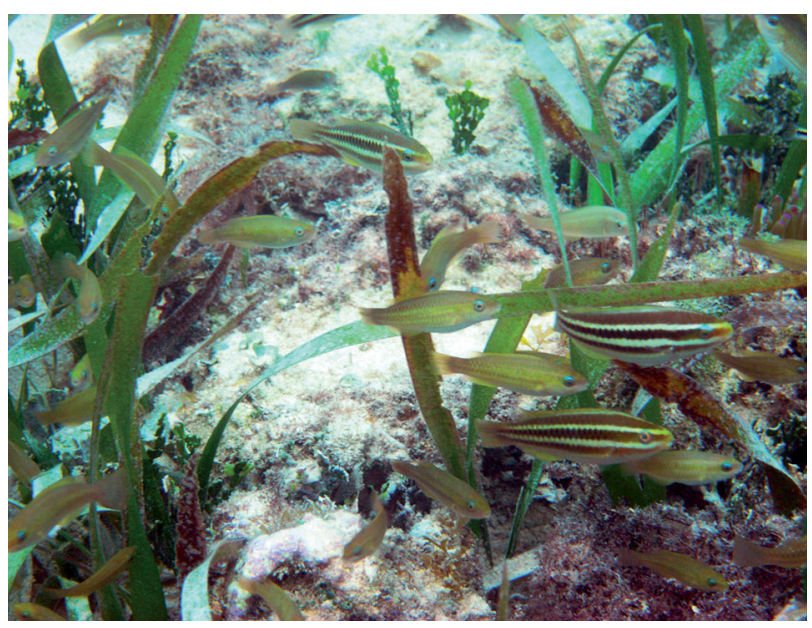

Herbivorous fish grazing within the seagrass canopy.

Photo: John Carroll

depending on local hydrogeological conditions, the majority of outflow locations occur in close proximity to land (Johannes 1980). This flux of groundwater can cause localized changes in water temperature, salinity and nutrient concentrations. As groundwater travels through terrestrial watersheds and aquifers into a submarine source, it becomes enriched with nutrients from the degradation and remineralization of organic matter as well as from fertilizer, manure and septic tank leachates that percolate into surficial sediments (Johannes 1980, Capone \& Baustista 1985). As a result, many coastal systems experience some level of eutrophication from submarine groundwater (Gobler \& Sañudo-Wilhelmy 2001, Gobler \& Boneilo 2003, Bowen et al. 2007). However, in oligotrophic tropical environments, the input of this nutri- 
ent-enriched submarine groundwater can represent a substantial source of allochthonous nutrients to these systems (Carruthers et al. 2005).

The northern coast of Jamaica is composed of highly permeable limestone that allows rainwater to rapidly enter the aquifer system, directly influencing the intensity of the submarine groundwater flow and the potential for land-derived nutrients to enter the water table and be transported to the coastal lagoons (D'Elia et al. 1981, Hine et al. 1991, Greenaway \& Gordon-Smith 2006). In this region of Jamaica, groundwater enters coastal zones either through fissures in the ocean bottom or by diffusing through the sediment (Slomp \& van Cappellen 2004). As groundwater flows through the karstic aquifers and surficial carbonate sediments, phosphorous (P) is stripped from the water via surface chemisorption, resulting in a P-depleted, nitrogen (N)-enriched outflow (Kitano et al. 1978, Koch 2001).

In Discovery Bay, Jamaica, D'Elia et al. (1981) found that groundwater entering the bay typically

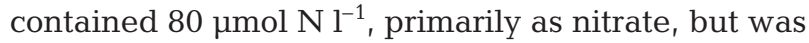
essentially devoid of dissolved inorganic phosphorous (DIP). Similarly, recent studies found significantly higher levels of nitrate and ammonium in areas of the bay possessing high SGD than in those not directly influenced by groundwater (Greenaway \& GordonSmith 2006). The nitrate levels were more than 2 orders of magnitude greater than those of most tropical coastal waters (Lapointe 1997), and because the submarine springs that feed Discovery Bay are a significant source of nitrate, there is a strong inverse relationship between salinity and nitrate concentration within the bay (D'Elia et al. 1981).

Point-source nutrient loading often elicits an increase in microalgal and macrophyte biomass and production, particularly in tropical systems (Bowen et al. 2007); therefore, it is possible that SGD is positively affecting benthic productivity in Discovery Bay. Seagrasses have extensive root systems and are more likely to be influenced by the presence of $\mathrm{N}$-enriched groundwater seepage than non-rhizophytic algae (Carruthers et al. 2005). The importance of porewater nutrients in determining seagrass productivity and leaf tissue nutrient content is well established (Fourqurean et al. 1992, 2002, Peterson \& Heck 2001). Therefore, we predicted that seagrasses growing within zones of N-enriched groundwater would display increased productivity, higher amounts of aboveground biomass and increased leaf tissue $\mathrm{N}$ levels.

SGD may also enhance rates of seagrass herbivory. Within SGD zones, the increased $\mathrm{N}$ availability and consequent nutritional quality of seagrass leaves may result in greater consumer activity. In terrestrial studies, herbivores preferentially consume plant tissues enriched in N (Levine et al. 1998, Haddad et al. 2001). Sala et al. (2008) recently demonstrated the positive impact of increasing salt marsh $\mathrm{N}$ levels on insect herbivory. Similarly, there is growing evidence that plant selection and preference by herbivores may be common in marine systems (McGlathery 1995, Boyer et al. 2004, Goecker et al. 2005, Furman \& Heck 2008). McGlathery (1995) established that herbivorous fish selected Thalassia testudinum with higher $\mathrm{N}$ contents in the field. Laboratory experiments by Goecker et al. (2005) demonstrated that the bucktooth parrotfish Sparisoma radians preferentially consumed $T$. testudinum leaves containing higher $\mathrm{N}$ levels even when visual cues appeared to be non-existent. In addition, Boyer et al. (2004) showed that herbivory increased in multiple habitats (coral reefs, mangroves and seagrass beds) when nutrient levels were elevated in the grazing material.

In the present study, we investigated the effects of SGD on the growth, productivity and $\mathrm{N}$ content of Thalassia testudinum beds in Discovery Bay, Jamaica. We further explored how grazing on groundwater-influenced seagrass compared to grazing on beds that were not directly influenced by groundwater. We predicted that SGD would positively affect growth, productivity and $\mathrm{N}$ content of $T$. testudinum and that it would be selectively consumed by herbivores, potentially mitigating its effect on biomass. Three specific questions were addressed in this study: (1) Was the productivity of $T$. testudinum higher in areas with groundwater input than in areas without? (2) In areas with groundwater inputs, were there higher concentrations of $\mathrm{N}$ in the leaf tissues of T. testudinum? (3) If so, did herbivores choose to disproportionately consume the high-N seagrass leaves in the field?

\section{MATERIALS AND METHODS}

\section{Study sites}

Experiments were conducted in 2 seagrass beds located on opposite sides of Discovery Bay, Jamaica (D'Elia et al. 1981). The western site (with groundwater present, GW; $18.470969^{\circ} \mathrm{N},-77.415848^{\circ} \mathrm{W}$ ) was a large Thalassia testudinum meadow situated in an area of visible groundwater flux and $2.2 \mathrm{~m}$ depth (mean low water). The SGD had no direct point source but instead percolated through calcium carbonate silt and sand into the water column. 
The eastern site (without groundwater, NGW; $18.469341^{\circ} \mathrm{N},-77.403703^{\circ} \mathrm{W}$ ) was an expansive seagrass meadow found at $3.3 \mathrm{~m}$ depth (mean low water). To our knowledge, there are no known groundwater inputs to the eastern site. Both sites are located inside the bay, behind the reef crest, where they remain protected from high wave action and current flow. Each meadow was a monoculture of $T$. testudinum, with mean densities of $466 \pm 94$ shoots $\mathrm{m}^{-2}$ at the west site and $588 \pm 107$ shoots $\mathrm{m}^{-2}$ at the east site and between 70 and $100 \%$ coverage in both of the study areas. The sites were chosen based on the health and density of the seagrass beds and similarities in depth and substrate. The major seagrass consumers in Discovery Bay are the bucktooth parrotfish Sparisoma radians and the sea urchin Tripneustes ventricosus. These 2 species were present at both study sites and were observed within the boundaries of each experimental area.

\section{Salinity and nutrients}

A stratified random sampling design was used to quantify the existence of an SGD-induced salinity gradient between the 2 sites. Salinity was measured using a YSI 85 CTD with readings taken within $0.5 \mathrm{~m}$ of the surface and bottom. The salinity was plotted using Ocean Data View software to create a contour plot of each area. Triplicate seawater samples were collected from each sampling location, and triplicate groundwater samples were collected from a spring directly north of the discharge zone in Discovery Bay. All of the samples were filtered $(0.45 \mu \mathrm{m})$ and analyzed using standard wet chemical, spectrophotometric methods within $48 \mathrm{~h}$ of collection (Parsons et al. 1984).

\section{Seagrass shoot morphometrics}

A total of 100 Thalassia testudinum short shoots (SS) were collected from each site for morphometric comparison. The number of leaves, leaf width, leaf length and leaf epibiont biomass $\left(\mathrm{mg} \mathrm{cm}^{-2}\right)$ were determined from the harvested shoots. Epibiont mass was determined by scraping fouling organisms and algae from each leaf and drying the leaves to a constant mass $( \pm 0.01 \mathrm{mg})$ in an oven at $60^{\circ} \mathrm{C}$. Following dry weighing, the ash weight was determined by combusting the samples at $500^{\circ} \mathrm{C}$ for $4 \mathrm{~h}$. Ash-free dry weights (AFDW) were calculated as the dry weight less the ash weight.

\section{Seagrass productivity}

At each site, 6 quadrats $(10 \times 15 \mathrm{~cm})$ were haphazardly set in the middle of the seagrass meadow for productivity measurements of Thalassia testudinum. Leaf production was measured using a modified leafmarking method (Zieman 1974). Within each $0.015 \mathrm{~m}^{2}$ quadrat, all of the seagrass shoots were marked near the base by piercing an 18-gauge hypodermic needle through all of the leaves. The marked shoots were allowed to grow for $8 \mathrm{~d}$, after which all of the aboveground seagrass material was harvested. Following the methods of Peterson \& Heck (2001), the daily gross above-ground production, above-ground seagrass biomass, SS density and number of bite marks were determined from the harvested shoots. Each shoot was separated into old growth and new growth, dried to a constant mass $( \pm 0.01 \mathrm{mg})$ in an oven at $60^{\circ} \mathrm{C}$ and weighed to obtain the dry weight. Seagrass productivity was calculated based on increases in both mass and leaf area.

\section{Sediment and leaf-tissue nutrient analysis}

To assess nutrient content, 10 sediment cores and 30 seagrass shoots were collected from each site. The sediment samples were dried at $60^{\circ} \mathrm{C}$ for at least $48 \mathrm{~h}$ and homogenized by milling to a fine powder. Total carbon (C) and $\mathrm{N}$ contents of the sediment samples were determined for each treatment by oxidation in a Fisons NA Model 1500 CNS analyzer. Phosphorus content was measured using the dry oxidation/acid hydrolysis procedure described by Fourqurean et al. (1992) for total particulate P determination.

To document any changes in the total $\mathrm{N}$ and $\mathrm{P}$ concentrations in leaves due to the presence of groundwater intrusion, biomass-specific changes were measured in the concentrations of $\mathrm{C}, \mathrm{N}$ and $\mathrm{P}$ in the dried leaves following Fourqurean et al. (1992). The 30 shoots from each site were randomly assigned into groups of 3 shoots, and the leaves were gently scraped and washed in flowing tapwater to remove epibionts and sediments that had adhered to the leaves. These washed samples were dried to a constant mass and homogenized by milling to a fine powder. Elemental contents of $\mathrm{C}, \mathrm{N}$ and $\mathrm{P}$ of the leaves were then determined as described above for the sediments. Data are presented as mole:mole ratios.

\section{Herbivore preference experiment}

Two herbivory preference experiments were conducted in the field using reciprocal transplant teth- 
ers. Seagrass grazing was quantified as described by Kirsch et al. (2002). Thalassia testudinum shoots were collected from each site and brought back to the lab. Undamaged leaves were severed from the shoots, then digitally scanned (using a Hewlett Packard flat-bed scanner), reassembled and attached to a $0.25 \mathrm{~m}$ long sisal line with a clothespin. Each line (or tether) consisted of 3 evenly spaced shoots. Two sets of 10 tethers were staked down at each site; one set contained shoots from the GW site, the other set shoots from the NGW site, for a total of 20 tethers at each site. The tethers were anchored using wire stakes inserted into the sediment. The clothespins were buried in the sediment, thus simulating the orientation of natural shoots within seagrass beds (Hay et al. 1983). The tethers were retrieved and replaced after $24 \mathrm{~h}$. Leaves from the retrieved tethers were then rescanned, and the differences in area between the initial and final scanning were used to estimate the grazing intensity (Goecker et al. 2005). This process was repeated during each of 6 consecutive days in the first experiment. Thus, a total of 720 tethered shoots were exposed to grazers for a $24 \mathrm{~h}$ period during this experiment. Each of the 4 treatments (GW to GW, GW to NGW, NGW to GW and NGW to NGW) consisted of 180 tethered shoots. To reduce the confounding influence of epiphytic load on herbivore choice, a second experiment was conducted during which the epiphytes were removed from the grass blades prior to tether deployment. This experiment was repeated during each of 3 consecutive days, exposing a total of 360 tethered shoots to herbivores (90 tethered shoots for each of the 4 treatments).

\section{Statistical analysis}

Two-tailed $t$-tests were used to determine significant differences between sites in seagrass leaf morphometrics, leaf nutrient content and productivity. One-way ANOVA was used to compare the grazing intensity between treatments in the reciprocal transplant experiment. Prior to statistical analysis, percentage data were log transformed. Two-way ANOVA was used to test for differences between the separate reciprocal transplant experiments, where the main factors were epiphyte presence and treatments. When assumptions of normality were not met, a MannWhitney rank sum test was performed.
When significant treatment effects were detected, post-hoc multiple comparison tests (Tukey's studentized range) were used to test for significant differences among treatments. All statistical analyses were conducted using the SigmaStat 3.0 statistical software package and were considered to be significant at $p<0.05$. Values in the text are mean \pm SD.

\section{RESULTS}

\section{Salinity and nutrients}

Surface salinity at the GW site ranged between 26.5 and 29 within the direct area of groundwater input. A contour plot of salinity (Fig. 1) shows the surface salinity differences within a $10 \mathrm{~m}$ radius of the GW site. The salinity of the NGW site, which lacks a groundwater source, varied little within a range of 33.8 to 34.5. Groundwater springs north of the GW site contained groundwater enriched in nitrate and silicate $(123 \pm 43$ and $72 \pm 3 \mu \mathrm{M}$, respectively) but void of ammonium and phosphate (Table 1). While the high nitrate and silicate signal was present in the water column at the GW site $(22.5 \pm 12.5$ and $19 \pm$ $2 \mu \mathrm{M}$, respectively), levels were substantially lower at the NGW site $(1.32 \pm 0.23$ and $2.1 \pm 0.5 \mu \mathrm{M}$, respectively; Table 1). Levels of ammonium and phosphate remained low at both sites in Discovery Bay.

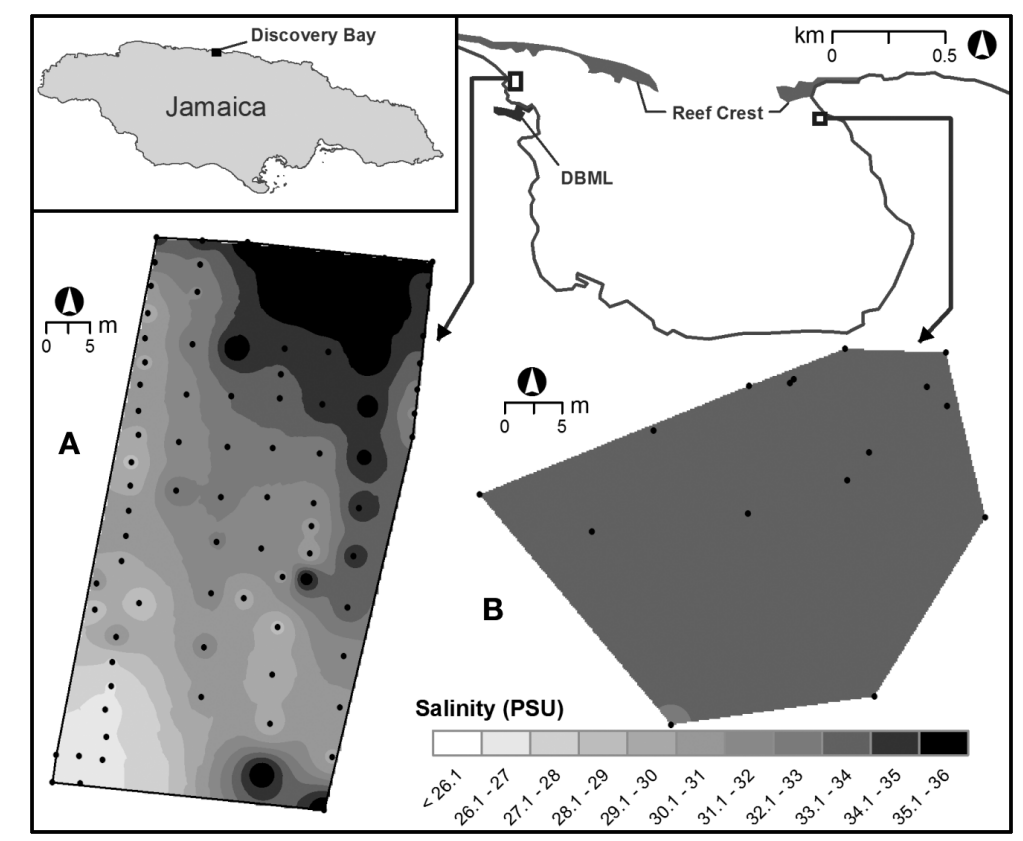

Fig. 1. Spatial plots of salinity at the (A) groundwater-present and (B) groundwater-absent sites. DBML: Discovery Bay Marine Lab 


\section{Seagrass shoot morphometrics}

Leaf length, width and number of leaves per shoot were all significantly greater at the GW site than at the NGW site ( $t$-test, $\mathrm{p}<0.001$ for all parameters). At the GW site, leaf length was $166.18 \pm 21.73 \mathrm{~mm}$, width was $13.34 \pm 1.14 \mathrm{~mm}$, and number of leaves per shoot was $3.24 \pm 0.44$. In contrast, at the NGW site, leaf length was $126.47 \pm 17.16 \mathrm{~mm}$, width was $10.11 \pm$ $1.16 \mathrm{~mm}$, and leaves per shoot was $2.69 \pm 0.33$. Total Thalassia testudinum above-ground material $\left(\mathrm{cm}^{2}\right.$ $\mathrm{SS}^{-1}$ ) was significantly higher at the GW site (MannWhitney rank sum test, $T=1737, \mathrm{p}<0.001$, Table 2 ) as was the leaf mass $\mathrm{SS}^{-1}(t=4.724, \mathrm{p}<0.001)$. T. testudinum standing crop (g dry wt $\mathrm{m}^{-2}$ ) was $105.75 \pm$ $26.75 \mathrm{~g} \mathrm{~m}^{-2}$ and $63.17 \pm 16.93 \mathrm{~g} \mathrm{~m}^{-2}$ at the GW and NGW sites, respectively. Epiphyte biomass standardized to leaf area showed that the NGW site had significantly more epiphyte biomass on the leaves than the GW site ( $t$-test, $t=3.30, \mathrm{p}<0.001$, Table 2$)$. Epiphytic biomass at the GW site was $7.68 \pm 1.73 \mathrm{mg} \mathrm{cm}^{-2}$ dry weight, while the biomass at the NGW site was $>2$-fold higher at $17.24 \pm 5.19 \mathrm{mg} \mathrm{cm}^{-2}$. Similarly, AFDW of epiphyte biomass at the GW site was $0.22 \pm$ $0.08 \mathrm{mg} \mathrm{cm}^{-2}$ and substantially greater at the NGW site at $0.83 \pm 0.058 \mathrm{mg} \mathrm{cm}^{-2}(t=3.310, \mathrm{p}<0.001)$.

\section{Seagrass productivity}

There were significant differences in estimated Thalassia testudinum productivity between the 2

Table 1. Salinity and nutrient levels $(\mu \mathrm{M})$ measured in samples $(\mathrm{n}=3$; mean $\pm \mathrm{SD}$ ) collected from each sampling sites and from a submarine groundwater spring north of the GW site in Discovery Bay, Jamaica. GW: groundwater present; NGW: groundwater absent

\begin{tabular}{|lccccc|}
\hline Site & Salinity & $\begin{array}{c}\text { Ammonium } \\
(\mu \mathrm{M})\end{array}$ & $\begin{array}{c}\text { Nitrate } \\
(\mu \mathrm{M})\end{array}$ & $\begin{array}{c}\text { Orthophos- } \\
\text { phate }(\mu \mathrm{M})\end{array}$ & $\begin{array}{c}\text { Silicate } \\
(\mu \mathrm{M})\end{array}$ \\
\hline Spring & $0 \pm 0$ & $0.5 \pm 0.1$ & $123 \pm 43$ & $0.13 \pm 0.1$ & $72 \pm 3$ \\
GW & $26.6 \pm 2.1$ & $0.3 \pm 0.3$ & $22.5 \pm 12.5$ & $0.11 \pm 0.09$ & $19 \pm 2$ \\
NGW & $33.7 \pm 0.57$ & $<0.2$ & $1.32 \pm 0.23$ & $0.04 \pm 0.03$ & $2.1 \pm 0.5$ \\
\hline
\end{tabular}

sites. The mass-specific productivity of the GW site was $7.03 \pm 1.67 \mathrm{mg} \mathrm{SS}^{-1} \mathrm{~d}^{-1}$ compared to $2.65 \pm$ $0.79 \mathrm{mg} \mathrm{SS}^{-1} \mathrm{~d}^{-1}$ at the NGW site. Correspondingly, leaf-area productivity was $1.546 \pm 0.28 \mathrm{~cm}^{2} \mathrm{SS}^{-1} \mathrm{~d}^{-1}$ at the GW site and $0.625 \pm 0.18 \mathrm{~cm}^{2} \mathrm{SS}^{-1} \mathrm{~d}^{-1}$ at the NGW site ( $t$-test, $t=6.568, \mathrm{p}<0.001$; Table 2$)$. Using either metric, the productivity of $T$. testudinum at the GW site was at least double that at the NGW site.

\section{Sediment and leaf-tissue nutrient analysis}

Sediment $\mathrm{N}$ and C:N ratios were significantly different between the sites with and without SGD ( $p<$ 0.001 for all parameters). The GW site sediment had $0.092 \pm 0.012 \% \mathrm{~N}$ and $11.61 \pm 0.45 \% \mathrm{C}$, while the NGW site had $0.053 \pm 0.006 \% \mathrm{~N}$ and $10.66 \pm 0.45 \%$ $\mathrm{C}$ ( $t$-test, $t=8.756$; Table 2). This resulted in sediment $\mathrm{C}: \mathrm{N}$ ratios of $148.75 \pm 17.94$ and $238.02 \pm 28.52$ at the GW and NGW site, respectively. Total sediment $\mathrm{P}$ was not significantly different between sites and averaged $0.039 \pm 0.006 \%$ P. These sediment differences were reflected in the seagrass leaf tissues. Leaf nutrient content in the GW site was significantly enriched in $\mathrm{N}(t=6.325, \mathrm{p}<0.001$; Table 2$)$. Leaf tissue at the GW site was $1.79 \pm 0.23 \%$, and at the NGW site $1.44 \pm 0.12 \%$. Leaf tissue $\mathrm{C}$ was also significantly enriched at the GW site $(t=6.782, \mathrm{p}<0.001)$, with $29.92 \pm 2.90 \%$ compared to $27.14 \pm 2.50 \%$ at the NGW site. There was no significant difference in leaf tissue $\mathrm{P}$ between the sites $(t=1.283, \mathrm{p}=0.47)$, with $0.12 \pm 0.05 \%$ and $0.14 \pm 0.03 \%$ at the GW and NGW site, respectively. However, as a result of the enriched $\mathrm{N}$ content, groundwater intrusion significantly decreased the leaf tissue C: $\mathrm{N}$ ratios $(t=6.568, \mathrm{p}<0.001$; Table 2) and increased the C:P and N:P ratios ( $t$-test, $t=6.234, \mathrm{p}<0.001$ and $t=$ $6.574, \mathrm{p}<0.001$, respectively; Table 2). The leaf tissue C:N, C:P and N:P ratios were $19.54 \pm 1.47,692.39 \pm 234.30$ and $36.52 \pm 12.88$ for the GW site and $21.99 \pm$ $1.92,453.69 \pm 115.99$ and $22.11 \pm 5.86$ for the NGW site, respectively.

Table 2. Differences in plant and sediment response variables between the groundwater present (GW) and groundwater absent (NGW) sites in Discovery Bay, Jamaica (means $\pm \mathrm{SD}$ )

\begin{tabular}{|c|c|c|c|c|c|c|c|}
\hline \multirow{2}{*}{ Site } & \multirow{2}{*}{$\begin{array}{l}\text { Above-ground } \\
\text { matter }\left(\mathrm{cm}^{2} \mathrm{SS}^{-1}\right)\end{array}$} & \multirow{2}{*}{$\begin{array}{l}\text { Epiphytic biomass } \\
\left(\mathrm{mg} \text { dry wt } \mathrm{cm}^{-2} \text { ) }\right.\end{array}$} & \multirow{2}{*}{$\begin{array}{l}\text { Seagrass produc- } \\
\text { tivity }\left(\mathrm{cm}^{2} \mathrm{SS}^{-1} \mathrm{~d}^{-1}\right)\end{array}$} & \multirow{2}{*}{$\begin{array}{l}\text { Sediment } \\
\mathrm{N}(\%)\end{array}$} & \\
\hline & & & & & $\mathrm{N}(\%)$ & $\mathrm{C}: \mathrm{N}$ & $\mathrm{C}: \mathrm{P}$ \\
\hline GW & $73.86 \pm 18.47$ & $7.68 \pm 1.73$ & $1.55 \pm 0.288$ & $0.092 \pm 0.012$ & $1.79 \pm 0.238$ & $19.54 \pm 1.47$ & $692.39 \pm 34.30$ \\
\hline NGW & $34.79 \pm 7.49$ & $17.2 \pm 5.19$ & $0.625 \pm 0.188$ & $0.053 \pm 0.007$ & $1.44 \pm 0.122$ & $21.99 \pm 1.92$ & $453.69 \pm 115.99$ \\
\hline
\end{tabular}




\section{Herbivore preference experiment}

Due to the significant differences in epiphytic biomass on the leaves between the 2 sites (NGW > GW; see 'Seagrass shoot morphometrics'), this experiment was replicated following epiphyte removal. A 2-way ANOVA revealed that the absence of epiphytes had no impact on the outcome of the treatment effects observed when the epiphytes were present $(F=$ $0.765, \mathrm{p}=0.65)$. Therefore, the results of both experiments were pooled.

Nutrient-mediated grazing intensity varied significantly between the treatment tethers (1-way ANOVA, $F=18.01$, p $<0.001$; Fig. 2). The shoots that were harvested from the GW site and transplanted to the NGW site averaged $7.86 \pm 0.75 \%$ consumption in a $24 \mathrm{~h}$ period, while the consumption of NGW shoots transplanted to GW was more than 2-fold greater $(16.66 \pm 0.49 \%, p<0.001)$. Control shoots that were tethered and returned to their harvest locations averaged $5.76 \pm 1.32 \%(\mathrm{GW})$ and $4.86 \pm 1.38 \%(\mathrm{NGW})$ consumption.

\section{DISCUSSION}

Oligotrophic tropical marine systems can respond quickly to nutrient enrichment (Lapointe 1997). However, the present study demonstrates that the mode of introduction can influence the relative contribution of benthic vs. pelagic production within the system. SGD represented a significant addition of

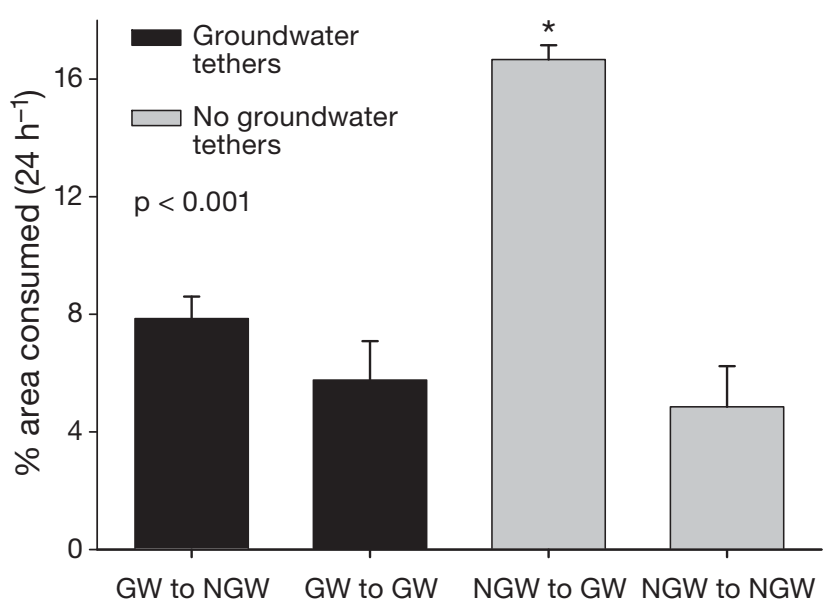

Fig. 2. Differences in grazing intensity on tethered shoots of Thalassia testudinum between the groundwater-present (GW) and groundwater-absent (NGW) sites in Discovery Bay, Jamaica (mean $\pm \mathrm{SD}$ ). Only the tethers transplanted from the NGW to GW site were significantly different from the others $(p<0.05$, Tukey's multiple comparison test) allochthonous $\mathrm{N}$ into this shallow coastal lagoon. Had this nutrient enrichment been introduced to the water column directly, ecological theory would suggest that planktonic and epiphytic algae would have responded to this 'bottom-up' increase in resource availability with increased productivity and biomass. Here, increased $\mathrm{N}$ did lead to significant increases in productivity and biomass, but it was the rooted benthic macrophytes (i.e. seagrasses) that responded rather than the epiphytic algae. In fact, epiphytic loads on the seagrass leaves in this study were greatest at the NGW site, where there was no nutrient source, a response we attributed to significantly slower growth rates of NGW shoots.

The elemental stoichiometry in tissue of primary producers has been shown to be a good integrator and indicator of ecological processes (Fourqurean \& Zieman 2002). The Redfield ratio (Redfield 1958), for example, can be used as an indicator of the relative availability of essential plant nutrients for phytoplankton communities. The same technique has also been applied to more structurally complex primary producers. Deviations from a taxon-specific Redfield ratio have been used as proxies for the relative nutrient availability for seagrasses (550:30:1) (Atkinson \& Smith 1983, Duarte 1990). Spatial patterns in elemental stoichiometry are caused by spatial variations in the local environment.

In the present study, the spatial pattern of resource availability recorded in the elemental stoichiometry of the Thalassia testudinum leaves corresponded to the nutrient patterns observed in the sediments. Both the sediment and leaf tissue nutrient contents clearly identified the groundwater sites as enriched in total $\mathrm{N}$ but not in total P. Seagrasses with more than $1.8 \%$ $\mathrm{N}$ tissue content are not predicted to respond to increased enrichment (Duarte 1990). The shoot $\mathrm{N}$ content at the GW site was at this $1.8 \%$ threshold for $\mathrm{N}$ limitation. Furthermore, the shoot N:P ratio at the GW site was 36.5:1, above the 30:1 ratio indicative of a balance between $\mathrm{N}$ and P supply (Atkinson \& Smith 1983). This finding suggests that $P$ was limiting growth at this site. The presence of $\mathrm{N}$-enriched groundwater coincided with dramatic impacts on seagrass shoot morphology and productivity, creating localized areas of enhanced productivity and biomass across the coastal landscape. T. testudinum is a sensitive indicator of increasing $N$ loads, with measurable increases in productivity, leaf area (Green \& Webber 2003) and leaf tissue $N$ levels. Although belowground biomass was not assessed in the present study, plants under sediment nutrient-deficient conditions increase biomass allocation to below- 
ground tissues to expand the surface area for nutrient uptake (Gleeson 1993, Vogt et al. 1993). Therefore, it is likely that the $\mathrm{N}$-enriched groundwater resulted in a greater allocation of $\mathrm{C}$ to the shoots.

Ultimately, the productivity and biomass of primary producers are influenced by the interactions of resource availability and herbivore consumption (Tilman 1977, Armitage \& Fourqurean 2006). Herbivory has been demonstrated to have a significant effect on seagrass density (Thayer et al. 1984, Valentine \& Heck 1999, Maciá \& Robinson 2005, Armitage \& Fourqurean 2006). Previous work has revealed that 3 to $10 \%$ of tethered Thalassia testudinum leaf tissue is often consumed within $24 \mathrm{~h}$ (Hay et al. 1983, Kirsch et al. 2002, Goecker et al. 2005). The grazing rates in our study were within that range for the tethers that were transplanted back to their original sites (4.87 to $5.76 \%$ ) and for the GW tethers transplanted to the NGW site $(7.86 \%)$. However, the consumption rates for the NGW tethers at the GW site were $>2$-fold greater than those observed on the other tethers $(16.66 \%)$. The pattern of bite marks in our study indicated that the herbivory in our reciprocal transplant experiment can be attributed primarily to parrotfish (Scaridae).

$\mathrm{N}$ enrichment of leaves did not elicit enhanced herbivore grazing during the present study. A similar outcome of $\mathrm{N}$ enrichment was recently demonstrated for eelgrass Zostera marina (Tomas et al. 2011). This finding contrasts with many studies of terrestrial plant-animal interactions in which herbivores have been shown to selectively consume plants with high $\mathrm{N}$ concentrations in their tissues (McNeill \& Southwood 1978, Mattson 1980, Bertness et al. 2008). Several marine studies have similarly documented elevated grazing pressure on $\mathrm{N}$-enriched plant tissue (McGlathery 1995, Boyer et al. 2004, Goecker et al. 2005, Furman \& Heck 2008). The availability of nutrient resources is reflected within plants via increased growth, nutrient content and defensive chemicals. The carbon-nutrient hypothesis (Herms \& Mattson 1992) predicts that carbon-based plant defenses will be highest under nutrient deficiency, when $\mathrm{C}$ can be allocated to secondary compounds, such as polyphenolics, at an energetically low cost. Thus, with improving nutrient availability, the assumption is that levels of these secondary compounds will decrease. The seagrass investigated in this study, Thalassia testudinum, has been shown to contain phenolic compounds (Zapata \& McMillian 1979), which decrease with increasing $\mathrm{N}$ leaf content (Goecker et al. 2005). However, herbivores clearly preferred $T$. testudinum that did not contain higher concentrations of $\mathrm{N}$ in the present study.
We hypothesized that N-rich seagrass shoots associated with the GW would experience the greatest consumption at the NGW site, but we observed the opposite. We noted a statistically significant difference in epiphytic loads between the sites, with greater loads of epiphytes on the leaves of the NGW shoots. This finding prompted us to replicate the experiment with the epiphytes removed from the leaves. The second reciprocal transplant experiment revealed that the presence (or absence) of the epiphytes had no impact on the grazing intensity of the seagrass tether treatments. The results of this second experiment mirrored the first. This result was not surprising given that the epiphytic loads of the leaves were comparatively low for both sites initially. Although the loads were statistically significant, they did not result in a significant difference in grazing intensity. The carbon-nutrient hypothesis and previous studies that have examined polyphenolic compounds in Thalassia testudinum (Goecker et al. 2005) suggest that these defensive chemicals, if present, would be greater in the unenriched shoots at the NGW site, which exacerbates the dilemma of the observed pattern of consumption.

Why might the herbivores have preferentially consumed the leaves that were not enriched in $\mathrm{N}$ at the GW site? Recent studies examining the ecological stoichiometry or the explicit simultaneous consideration of multiple nutritional requirements (especially $\mathrm{C}, \mathrm{N}$ and $\mathrm{P}$ ) may address this particular interaction of primary producers and herbivores. In contrast to classical arguments in favor of N limitation, stoichiometric analyses suggest that plant $\mathrm{P}$ content may be an important but unrecognized limiting nutrient for many terrestrial (Sterner \& Elser 2002) and aquatic (Elser et al. 2000) herbivores. This may be especially true in tropical marine systems, where $\mathrm{P}$ is typically limited because of the carbonate sediments. Although relatively few studies have sought evidence for $\mathrm{P}$ sensitivity in herbivores, in a review of how plant nutrient stress impacts insect herbivores, Waring \& Cobb (1992) identified several fertilization experiments that showed positive responses of herbivores to leaf $\mathrm{P}$ content. In addition, several recent studies have demonstrated that increased P leaf tissue content affected herbivore dynamics (Campo \& Dirzo 2003, Schade et al. 2003, Apple et al. 2009). The current hypothesis regarding these studies is that the ratio of N:P in plant leaves is $\sim 20 \%$ greater than in the average herbivore, leading to $\mathrm{P}$ limitation in the grazer (Apple et al. 2009). Given the unambiguous repeated outcome of the reciprocal transplant experiments, we interpret the herbivores' pref- 
erential selection of seagrass shoots enriched in $\mathrm{P}$ $(\mathrm{N}: \mathrm{P}=22)$ within a meadow of $\mathrm{N}$-enriched shoots $(\mathrm{N}: \mathrm{P}=36)$ as an example of the herbivores responding to the ecological stoichiometry of the plants and preferentially grazing P-enriched seagrasses. Given the strong groundwater source of $\mathrm{N}$ in this region and the heavy $\mathrm{N}$ enrichment of seagrass leaves here, the need for herbivores to supplement their diets with $\mathrm{P}$ is likely more profound than in other areas.

In conclusion, the submarine groundwater significantly enhanced the morphology, leaf tissue $\mathrm{N}$ content and productivity of the Thalassia testudinum shoots associated with the discharge. This finding indicates that when present, groundwater can create 'hot-spots' of plant biomass and productivity within the oligotrophic coastal landscape. However, the expected herbivore response to the increase in leaf $\mathrm{N}$ content was not observed, indicating a lack of trophic transfer of the increased seagrass productivity in this lagoon. In fact, the reciprocal transplant experiments demonstrated that herbivores actively selected shoots enriched with $\mathrm{P}$ relative to $\mathrm{N}$ within the groundwater site, which to the knowledge of the authors has not been previously demonstrated with seagrasses. Expanded research is required to ascertain the generality of the finding that herbivores preferentially graze on plant material enriched in $P$ in tropical marine systems where $\mathrm{P}$ is limiting.

Acknowledgements. The authors thank the students of MAR388: Tropical Marine Ecology for assisting with the field experiments, J. Myers for assisting with sample processing in the laboratory and J. Carroll and B. Furman for improving the quality of the manuscript. We also thank the Discovery Bay Marine Lab for their generous support and assistance. This is contribution 1410 from the School of Marine and Atmospheric Sciences at Stony Brook University.

\section{LITERATURE CITED}

Apple JL, Wink M, Wills SE, Bishop JG (2009) Successional change in phosphorus stoichiometry explains the inverse relationship between herbivory and lupin density on Mount St. Helens. PLoS ONE 4:e7807

Armitage AR, Fourqurean JW (2006) The short-term influence of herbivory near patch reefs varies between seagrass species. J Exp Mar Biol Ecol 339:65-74

> Atkinson MJ, Smith SV (1983) C:N:P ratios of benthic marine plants. Limnol Oceanogr 28:568-574

Bertness MD, Crain C, Holdredge C, Sala N (2008) Eutrophication and consumer control on New England salt marsh primary productivity. Conserv Biol 22:131-139

> Bowen JL, Kroeger KD, Tomasky G, Pabich WJ, Cole ML, Carmichael RH, Valiela I (2007) A review of land-sea coupling by groundwater discharge of nitrogen to New England estuaries: mechanisms and effects. Appl Geochem 22:175-191
Boyer KE, Fong P, Armitage AR, Cohen RA (2004) Elevated nutrient content of tropical macroalgae increases rates of herbivory in coral, seagrass, and mangrove habitats. Coral Reefs 23:530-538

- Campo J, Dirzo R (2003) Leaf quality and herbivory responses to soil nutrient addition in secondary tropical dry forests of Yucatán Mexico. J Trop Ecol 19:525-530

Capone DG, Baustista MF (1985) A groundwater source of nitrate in nearshore marine-sediments. Nature 313: 214-216

Carruthers TJB, van Tussenbroek BI, Dennison WC (2005) Influence of submarine springs and wastewater on nutrient dynamics of Caribbean seagrass meadows. Est Coast Shelf Sci 64:191-199

D'Elia CF, Webb KL, Porter JW (1981) Nitrate-rich groundwater inputs to Discovery Bay, Jamaica: A significant source of N to local coral reefs? Bull Mar Sci 31:903-910

> Duarte CM (1990) Seagrass nutrient content. Mar Ecol Prog Ser 67:201-207

- Elser JJ, Fagan WF, Denno RF, Dobberfuhl DR and others (2000) Nutritional constraints in terrestrial and freshwater food webs. Nature 408:578-580

> Fourqurean JW, Zieman JC, Powell GVN (1992) Phosphorus limitation of primary production in Florida Bay: evidence from C:N:P ratios of the dominant seagrass, Thalassia testudinum. Limnol Oceanogr 37:162-171

Fourqurean JW, Zieman JC (2002) Nutrient content of the seagrass Thalassia testudinum reveals regional patterns of relative availability of nitrogen and phosphorus in the Florida Keys USA. Biogeochemistry 61:229-245

Furman BT, Heck KLJ (2008) Effects of nutrient enrichment and grazers on coral reefs: an experimental approach. Mar Ecol Prog Ser 363:89-101

Gleeson SK (1993) Optimization of tissue nitrogen and rootshoot allocation. Ann Bot 71:23-31

Gobler CJ, Sañudo-Wilhelmy SA (2001) Temporal variability of groundwater seepage and brown tide blooms in a Long Island embayment. Mar Ecol Prog Ser 217:299-309

Gobler CJ, Boneillo GE (2003) Impacts of anthropogenically influenced groundwater seepage on water quality and phytoplankton dynamics within a coastal marine ecosystem. Mar Ecol Prog Ser 255:101-114

> Goecker ME, Heck KL Jr, Valentine JF (2005) Effects of nitrogen concentrations in turtlegrass Thalassia testudinum on consumption by the bucktooth parrotfish Sparisoma radians. Mar Ecol Prog Ser 286:239-248

Green SO, Webber DF (2003) The effects of varying levels of eutrophication on phytoplankton and seagrass (Thalassia testudinum) populations of the southeast coast of Jamaica. Bull Mar Sci 73:443-455

Greenaway AM, Gordon-Smith DA (2006) The effects of rainfall on the distribution of inorganic nitrogen and phosphorus in Discovery Bay, Jamaica. Limnol Oceanogr 51:2206-2220

> Haddad NM, Tilman D, Haarstad J, Ritchie M, Knops JMH (2001) Contrasting effects of plant richness and composition on insect communities: a field experiment. Am Nat 158:17-35

Hay ME, Colburn T, Downing D (1983) Spatial and temporal patterns in herbivory on a Caribbean fringing reef: the effects on plant distribution. Oecologia 58:299-308

Herms DA, Mattson WJ (1992) The dilemma of plants: to grow or defend. Q Rev Biol 67:283-335

Hine AC, Land LS, Clayton TD, McCullough ML (1991) Seismic stratigraphy of Discovery Bay, Jamaica. Mar 
Geol 98:83-97

Johannes RE (1980) The ecological significance of the submarine discharge of groundwater. Mar Ecol Prog Ser 3:365-373

Kirsch KD, Valentine JF, Heck KL Jr (2002) Parrotfish grazing on turtlegrass Thalassia testudinum: evidence for the importance of seagrass consumption in food web dynamics of the Florida Keys National Marine Sanctuary. Mar Ecol Prog Ser 227:71-85

Kitano Y, Okumura M, Idogaki M (1978) Uptake of phosphate ions by calcium carbonate. Geochem J 12:29-37

Koch EW (2001) Beyond light: physical, geological, and geochemical parameters as possible submersed aquatic vegetation requirements. Estuaries 24:1-17

Lapointe BE (1997) Nutrient thresholds for bottom-up control of macroalgal blooms on coral reefs in Jamaica and southeast Florida. Limnol Oceanogr 42:1119-1131

Levine JM, Hacker SD, Harley CDG, Bertness MD (1998) Nitrogen effects on an interaction chain in a salt marsh community. Oecologia 117:266-272

Maciá S, Robinson MP (2005) Effects of habitat heterogeneity in seagrass beds on grazing patterns of parrotfishes. Mar Ecol Prog Ser 303:113-121

Mattson WJ (1980) Herbivory in relation to plant nitrogen content. Annu Rev Ecol Evol Syst 11:119-161

McGlathery KJ (1995) Nutrient and grazing influences on a subtropical seagrass community. Mar Ecol Prog Ser 122: 239-252

McNeill S, Southwood TRE (1978) The role of nitrogen in the development of insect/plant relationships. In: Harborne J (ed) Biogeochemical aspects of plant and animal coevolution. Proc Phytochemical Soc Symp, Academic Press, London, p 78-89

Parsons TR, Maita Y, Lalli CM (1984) A manual of chemical and biological methods for seawater analysis. Pergamon Press, Oxford

Peterson BJ, Heck KL Jr (2001) Positive interactions between suspension-feeding bivalves and seagrass: a facultative mutualism. Mar Ecol Prog Ser 213:143-155

Editorial responsibility: Brant Touchette,

Elon, North Carolina, USA
Redfield AC (1958) The biological control of chemical factors in the environment. Am Sci 46:205-221

Sala NM, Bertness MD, Silliman BR (2008) The dynamics of bottom-up and top-down control in a New England salt marsh. Oikos 117:1050-1056

Schade JD, Kyle M, Hobbie SE, Fagan WF, Elser JJ (2003) Stoichiometric tracking of soil nutrients by a desert insect herbivore. Ecol Lett 6:96-101

> Slomp CP, van Cappellen P (2004) Nutrient inputs to the coastal ocean through submarine groundwater discharge: controls and potential impact. J Hydrol (Amst) 295:64-86

Sterner RW, Elser JJ (2002) Ecological stoichiometry: the biology of elements from molecules to the biosphere. Princeton University Press, Princeton, NJ

> Thayer GW, Bjorndal KA, Ogden JC, Williams SL, Zieman JC (1984) Role of larger herbivores in seagrass communities. Estuaries 7:351-376

Tilman D (1977) Resource competition between planktonic algae: an experimental and theoretical approach. Ecology 58:338-348

Tomas F, Abbott JM, Steinberg C, Balk M, Williams SL, Stachowicz JJ (2011) Plant genotype and nitrogen loading influence seagrass productivity, biochemistry, and plant-herbivore interactions. Ecology 92:1807-1817

> Valentine JF, Heck KLJ (1999) Seagrass herbivory: evidence for the continued grazing of marine grasses. Mar Ecol Prog Ser 176:291-302

> Vogt KA, Publicover DA, Bloomfield J, Perez JM, Vogt DJ, Silver WL (1993) Belowground responses as indicators of environmental change. Environ Exp Bot 33:189-205

Waring GL, Cobb NS (1992) The impact of plant stress on herbivore population dynamics. In: Bernays EA (ed) Plant-insect interactions, Vol 4. CRC, Boca Raton, FL, p 167-226

Zapata O, McMillian C (1979) Phenolic acids in seagrasses. Aquat Bot 7:307-317

Zieman JC (1974) Methods for the study of the growth and production of turtle grass, Thalassia testudinum König. Aquaculture 4:139-143

Submitted: August 1, 2011; Accepted: February 13, 2012 Proofs received from author(s): March 14, 2012 